

\title{
Management strategies proposal for reducing the abundance of small organisms in the small pelagic fishery catch from the Gulf of California
}

\section{Propuesta de manejo para reducir la abundancia de organismos pequeños en la captura de la pesquería de pelágicos menores del Golfo de California}

\author{
Jesús Jurado-Molina ${ }^{1 \oplus ~ *}$, Carlos Humberto Hernández-López¹, Raúl Villaseñor-Talavera² ${ }^{2}$ Jessica Johana García-Meléndez ${ }^{1}$
}

Global Grupo de Gestión e Investigación en Ciencias y Tecnologías Marinas, Ambiente, Desarrollo Social y Alimentación A.C. Flamingos 510 Int. 8, entre Río Pánuco y Ferrocarrilera, Col. Ferrocarrilera, Mazatlán, Sinaloa, 82128. México.

${ }^{2}$ Colegio Nacional de Profesionales de la Pesca, A. C. Calle Pitágoras 748 , Col. Narvarte Poniente, CDMX, 03020 México.

*Corresponding author:

Jesús Jurado Molina: e-mail:

jjurado@uw.edu

To quote as:

Jurado-Molina J., C. H. Hernández-López, R. Villaseñor-Talavera \& J. J. García-Meléndez. 2020. Management strategies proposal for reducing the abundance of small organisms in the small pelagic fishery catch from the Gulf of California. Hidrobiológica 30 (1):49-60.

: 10.24275/uam//it/dcbs/hidro/2020v30n1/ Jurado

\section{ABSTRACT}

Background: Results indicate the fishery might be catching small California sardine in some fishing areas that could produce growth overfishing. Objectives: To estimate the percentage of organisms caught below the minimum size and determining the potential variables affecting the organisms size caught by the fishery. Methods: we did data exploratory analysis, correlation analysis and explored the size's seasonal and interannual variability. We used ANCOVA and ANOVA to find out the main driver determining sardine's size. The response variable was the standard length, the ANCOVA model included six covariates, six factors and the first level interactions. Results: the standard length ranged from $64 \mathrm{~mm}$ to $230 \mathrm{~mm}$, the mean was $158.6 \pm$ $19.8 \mathrm{~mm}$. Results suggest $32.9 \%$ of the organisms caught are below the minimum size, $12.9 \%$ above the tolerance limit (20\%). Regarding the seasonal variation, results suggest the lower standard length value occurred during June and July, while the highest occurred in March. The ANCOVA model included 60 significant predictors; it explained $82.2 \%$ of the observed variability. ANOVA results suggested that the predictor variable explaining the majority of the variability was the factor Month (31.5\%); the second was the factor year $(9.5 \%)$ and the third was Boat (7.2\%). Conclusions: Compliance with regulations would require reducing operations during June and July in zones IV-G and VI-G; this would help to avoid growth overfishing. However, it could face fishermen opposition that already face a close season. Regulations compliance would require that CONAPESCA and fishermen reach a consensus. Our results contribute to provide information to avoid growth overfishing and yield overfishing. They support the efforts that managers and fishermen are making to assure the sustainable exploitation of this fishing resource.

Key words: ANCOVA, ANOVA, California Sardine, Gulf of California, standard length

\section{RESUMEN}

Antecedentes: Los resultados indican que la pesquería captura organismos pequeños de sardina Monterrey en algunas áreas de pesca, lo cual produciría sobrepesca de crecimiento. Objetivos: Estimar el porcentaje de organismos debajo de la talla mínima y determinar las variables que afectan la talla de los organismos capturados. Métodos: Se uso análisis exploratorio de datos, correlación y la variabilidad estacional e interanual de la talla. Se usó ANCOVA y ANOVA para encontrar la variable responsable en la determinación de la talla de las sardinas. La longitud estándar fue la variable de respuesta, se incluyeron seis factores, seis covariables y las interacciones de primer nivel. Resultados: la longitud estándar vario de $64 \mathrm{~mm}$ a $230 \mathrm{~mm}$, el promedio fue de $158.6 \pm 19.8 \mathrm{~mm}$. Los resultados sugieren que $32.9 \%$ de los organismos están por debajo de la talla mínima, $12.9 \%$ arriba del límite. La menor talla se alcanzó en junio y julio, mientras que la más grande se alcanzó en marzo. El modelo ANCOVA incluyo 60 predictores significativos; explicó 82.2\% de la variabilidad observada. ANOVA sugiere que la variable que explica la mayor variabilidad fue el factor Mes, la segunda fue el factor Año y el tercero el factor Embarcación. Conclusiones: El cumplimiento de la norma requeriría reducir operaciones durante junio y julio en las zonas IV-G y VI-G; esta medida ayudaría a evitar la sobrepesca de crecimiento. Sin embargo, esto implicaría ampliar la veda y podría haber resistencia a dicha disposición. El cumplimiento de las regulaciones requiere que la CONAPESCA y los armadores alcancen un consenso. Los resultados del trabajo contribuyen a proveer información para evitar la sobrepesca. Apoyan los esfuerzos que las autoridades y los armadores hacen para asegurar la explotación sustentable de este recurso pesquero.

Palabras clave: ANCOVA, ANOVA, Golfo de California, Iongitud patrón, sardina Monterrey 


\section{INTRODUCTION}

The California sardine (Sardinops sagax, Jenyns 1842), locally known as sardina Monterrey, is a temperate species distributed from the Gulf of California to Kamchatka, Alaska (Miller \& Lea, 1972) and is part of the small pelagic fish. It is generally considered to be isolated in the Gulf of California from other subpopulations (Lluch-Belda \& Magallon, 1986), and it is found principally in the Gulf central region (Hammann et al., 1988). In the Gulf of California, estimates of California sardine abundance, as well as biomass, have shown great variability. Recruits number increased from the early seventies to a peak in the mid-eighties, falling to very low levels between 1990 and 1992, and again an upward trend with high variability until reaching a historical maximum in 2007 (INAPESCA, 2012).

Small pelagic is one of the main fishing resources around the world. In Mexico, it is the main fishing resource in terms of volume, sometimes representing up to $30 \%$ of the total annual catch in the country (INAPESCA, 2012; INAPESCA, 2018). Catch species composition varies, being the California sardine the most representative with $38 \%$ of catch (SADER, 2019). The sardine fishery moves south and north as these fish populations migrate south in the winter and spring, and north in the later spring and summer. The Mexican small pelagic fishery operates in the central gulf and, to a much smaller extent, along the west coast of southern Baja California (Lluch-Belda \& Magallon, 1986).

This fishing resource is an important source of quality protein for human consumption. The industry uses it as raw material for the production of balanced feed for poultry, swine, and aquaculture. The commercial (industrial and artisanal) and sport fishing use it as bait. Besides, this fishery is an important source of employment (Gómez-Muñoz et al., 1991; Cisneros-Mata et al., 1995; Lluch-Belda et al., 1996); it generates around 5,000 direct jobs and a similar amount of indirect jobs (INAPESCA, 2012).

Currently, the fleet consists of boats from 23 to 35 meters in length and 101 to 285 metric tons of hold capacity (SADER, 2019). Presently, 48 vessels operate in the Gulf of California. The fishery uses a purse seine net with an average mesh size of $25 \mathrm{~mm}$. Seine length varies between 366 and $640 \mathrm{~m}$, and seine height varies between 40 and $100 \mathrm{~m}$. All boats have hydroacoustic equipment for the location of fish schools. For fleet operations, a 40 NM radius of action has been established from the base port (Rodriguez et al. 1996). The fleet operates from two main ports (Mazatlán and Guaymas) and within several fishing zones in the Gulf of California (Figure 1).

The NOM-003-SAG/PESC-2018 regulates the small pelagic fishery with a minimum size for the California sardine of $150 \mathrm{~mm}$ of standard length (SADER, 2019). The standard also establishes the maximum volume of fishes caught below the minimum size being $20 \%$ of the total catch. Besides, the standard also defines boat characteristics, gear characteristics, and three fishing regions. It also suggests admitting onboard observers in $20-30 \%$ of trips for gathering information on fishing operations, species composition, bycatch, and ETP species catch.

According to the National fisheries chart (INAPESCA, 2018), the fishery is exploited at the maximum sustainable yield. In July 2011, the Marine Stewardship Council (MSC) certified as sustainable and well managed the 36 vessels fleet of the small pelagic fishery in the Gulf of California with the California sardine as target species and the purse seine as fishing gear. Keeping the MSC certification is of great importance for managers and the industry; therefore, during the 20162018 period, an onboard Observer Program collected important data during fishing operations, including biological and fishery information. However, preliminary results indicate that the fishery might be catching small organisms that could produce growth overfishing. In this paper, we used the onboard Observer Program data for the estimation of the percentage of organisms below the minimum size and for determining the potential variables affecting the sardine's size caught by the fishery, in an attempt to establish management measures that contribute to avoid growth overfishing and assure the sustainable exploitation of this fishing resource.

\section{MATERIAL AND METHODS}

Observer Programs are an important tool for gathering information for fisheries management. In particular, the small pelagic fishery in the Gulf of California had an Observer Program between 2016 and 2018 observers following a monitoring protocol (Jacob et al. 2018; Hernández \& Jurado, 2018).

Onboard observers took biological samples within the fishing operation zones in the Gulf of California (Fig. 1) during the 2017 and 2018 seasons using random stratified sampling. In 2017, biological samples came from 20 boats, the following year, samples came from 29 boats. Observers registered biological, physical, and technological variables. With those data, we carried out a data exploratory analysis. We analyzed seasonal size variation and the interannual size variation using the Kruskal-Wallis and the Wilcoxon's signed-rank test respectively. For the post hoc test we used the function posthoc.kruskal.nemenyi.test implemented in the $\mathrm{R}$ package. We also explored the size variation by mesh size (Kruskal-Wallis test), by Boat, and by Zone. Later, we investigated the potential predictor variables affecting the sardine's size caught by the purse seine fishery through analysis of correlation and covariance ANCOVA. For the maximal ANCOVA model, we defined the continuous response variable as the standard length. Continuous covariates included mesh size (MS), depth (D), latitude (Lat), longitude (Lon), seine length $(\mathrm{SL})$, and the sein height $(\mathrm{SH})$. On the other hand, factors included year $(\mathrm{Y})$, month (M), maturity (MA), Sex (Sex), fishing zone (Z), and boat (B). We included in the model first-level interactions and a normally distributed error $(\varepsilon)$ :

$L=\beta_{0}+\beta_{1} M+\beta_{2} Y+\beta_{3} M S+\beta_{4} D+\beta_{5} L a t+\beta_{6} L$ ong $+\beta_{7}$ Sex $+\beta_{8} M A+$
$\beta_{9} Z+\beta_{10} B+\beta_{11} S L+\beta_{12} S H+$ first level interactions $+\varepsilon$

We set up the model using the function $/ m$ from the statistical package $R$ ( $R$ core team 2018). The factor levels are shown below (Table 1). The model simplification process was done initially using the step function from the same statistical package. Later, we applied a manual stepwise process; in each step, we deleted a no significant term and applied ANOVA for the current model and the updated model (Crawley, 2007). The model simplification was justified if it caused a negligible reduction in the explanatory power of the model $(p>0.05)$. We repeated this procedure until all terms included in the model were significant; the resulting model was considered as the minimal and adequate model. Finally, we applied ANOVA to the minimum model to find out the amount of variability explained by each predictor variable. 




Figure 1. Fishing zones where the small pelagic fishery operates in the Gulf of California (modified from Jacob et. al, 2018).

\section{RESULTS}

The number of samples collected by the Onboard Observers Program distributed in each operating zone were: Zone I-G (615), Zone II-G (79), Zone III-G (1244), Zone IV-G (1219), Zone V-G (2379), Zone VI-G (514), Zone VII-G (504), Zone VIII-G (299), Zone IX-G (1730).

Regarding the size structure, the Observer Program's data suggest that the California sardine standard length in the Gulf of California ranged from $64 \mathrm{~mm}$ to $230 \mathrm{~mm}$, the average length was $158.6 \pm 19.8 \mathrm{~mm}$, with a median of $160 \mathrm{~mm}$. The standard length distribution is shown below (Figs. 2a and 2b); there are some outliers mainly in the lower end of the distribution (Fig. 2b). The distribution of the sardine's length is not normal $\left(p\right.$-value $\left.=2.2 \times 10^{-16}\right)$. Although the estimated mean is greater than the minimum size $(150 \mathrm{~mm})$ established in the regulation (SADER, 2019), results suggest that $32.9 \%$ of the organisms caught are below the minimum size (Fig. 3), 12.9\% above the established tolerance limit (20\%).

On regard to the seasonal variation (Fig. 4), results suggest the lower standard length values occurred during June $(142.8 \pm 18.9 \mathrm{~mm})$ and July $(135.9 \pm 19.0 \mathrm{~mm})$, while the highest values occur in March $(170.6 \pm 16.1 \mathrm{~mm})$ and April $(170.8 \pm 9.4)$. The Kruskal-Wallis rank sum test suggested that means are not all equal ( $p$-value $<2.2 \times 10^{-16}$ ). Results from the post hoc test also suggested that the monthly means for March and April are statistically the same $(\operatorname{Pr}(>I I)=1.0)$. Likewise,
Table 1. Factor levels used in the ANCOVA model (1) to assess the potential drivers of the caught sardine's length in the Gulf of California.

\begin{tabular}{ccccc}
\hline Year & Maturity & Fishing zone & Boat & Month \\
\hline 2017 & 1 & I-G & 1 & 1 \\
2018 & 2 & II-G & 2 & 2 \\
& 3 & III-G & 3 & 3 \\
& 4 & IV-G & 4 & 4 \\
& 5 & V-G & 5 & 5 \\
& & VI-G & 6 & 6 \\
& & VII-G & 7 & 7 \\
& & VIII-G & 8 & 8 \\
& IX-G & 9 & 9 \\
& & 10 & 10 \\
& & 11 & 11 \\
& & 12 & 12 \\
\hline
\end{tabular}


the mean for February is statistically equal to the means from March and April (Table 2), and the mean of January is statistically equal to the means from November $(\operatorname{Pr}(>\|)=0.34)$ and December $(\operatorname{Pr}(>\|)=0.24)$. The remaining mean comparations are statistically different (Table 2).
Regarding the interannual variation, results from the Wilcoxon rank sum test suggest that the mean standard length from 2017 (148.3 \pm $13.1 \mathrm{~mm})$ is significantly smaller than the mean $(162.9 \pm 20.1 \mathrm{~mm})$ from 2018 ( $p$-value $\left.<2.2 \times 10^{-16}\right)$.

a)

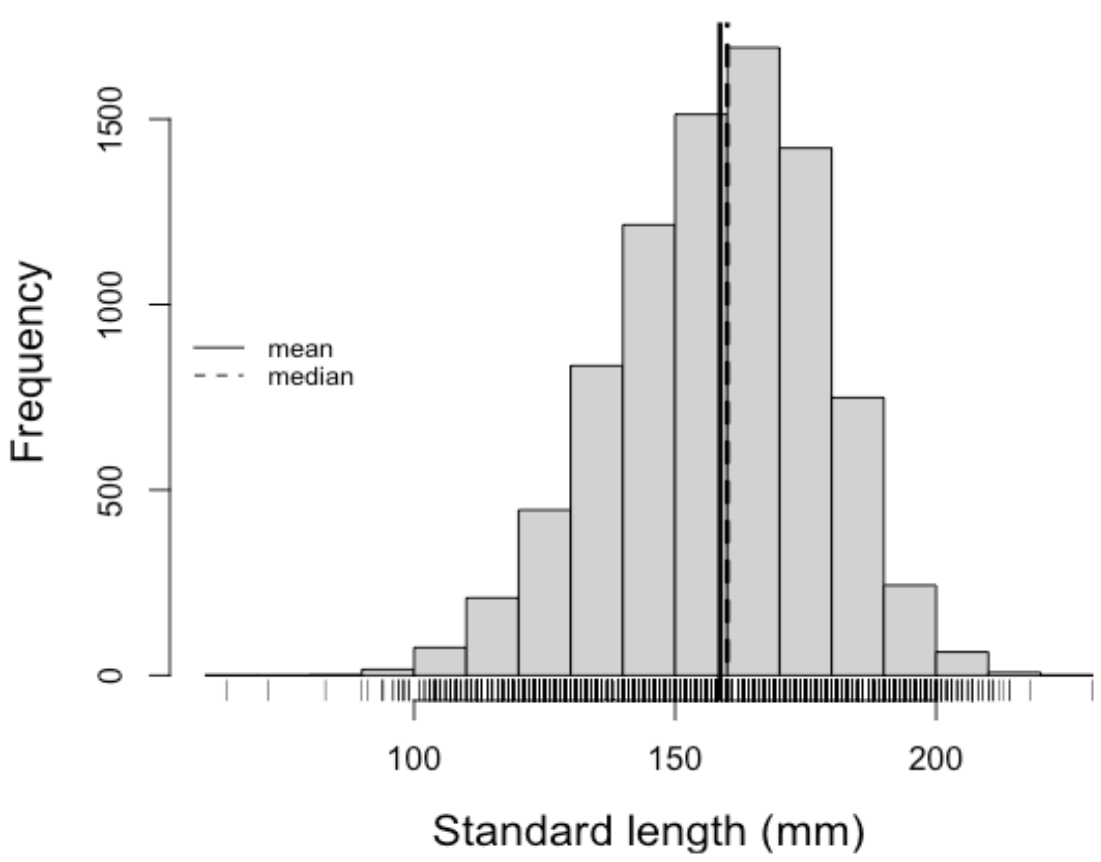

b)

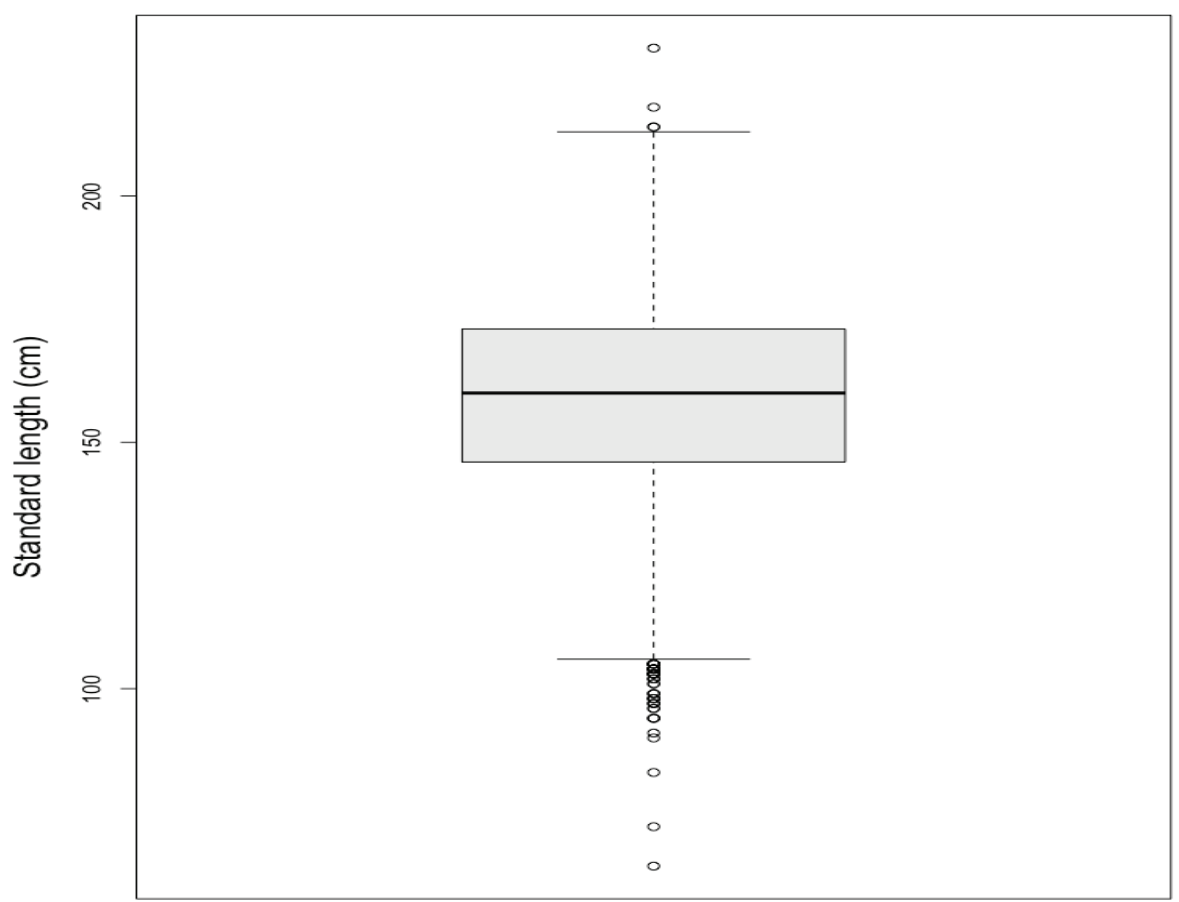

Figure 2. a) California sardine standard length distribution for 2017-2018 in the Gulf of California, b) Boxplot for the sardine standard length. 
Table 2. Results from the post hoc Kruskal-Wallis test for the sardine's standard length monthly average in the Gulf of California

\begin{tabular}{ccccccccc}
\hline Month & 1 & 2 & 3 & 4 & 5 & 6 & 7 & 10 \\
\hline 2 & $9.2 \times 10^{-14}$ & & & & & & & \\
3 & 0 & 0.18 & & & & & & \\
4 & 0 & 0.31 & 1 & & & & & \\
5 & $5.1 \times 10^{-06}$ & $6.1 \times 10^{-10}$ & $1.2 \times 10^{-13}$ & $1.1 \times 10^{-13}$ & & & & \\
6 & 0 & 0 & 0 & 0 & 0 & & & \\
7 & 0 & 0 & 0 & 0 & 0 & $3.2 \times 10^{-07}$ & & \\
10 & $2.3 \times 10^{-09}$ & 0 & 0 & 0 & $1.3 \times 10^{-14}$ & $3.1 \times 10^{-04}$ & $9.7 \times 10^{-14}$ & \\
11 & 0.34 & 0 & 0 & 0 & $4.4 \times 10^{-04}$ & 0 & 0 & $9.2 \times 10^{-14}$ \\
12 & 0.24 & $6.2 \times 10^{-14}$ & 0 & 0 & $9.4 \times 10^{-10}$ & $1.4 \times 10^{-13}$ & 0 & 0.04 \\
\hline
\end{tabular}

We estimated the mean standard length by zone (Table 3), the largest mean corresponded to the zone VIII-G $(174.9 \pm 20.1 \mathrm{~mm})$ while the smaller mean corresponded to the zone IV-G $(142.5 \pm 19.4 \mathrm{~mm})$. It is important to mention that the mean standard length in all zones was larger than the minimum size established, except for the zone IV-G.

On the other hand, the largest average standard length by mesh size corresponded to the mesh size of 1.2 inches, while the smallest coincided with the 0.5 inches and the 1.9 inches of mesh size (Table 4). The Kruskal-Wallis test suggested there was at least one mean that is different from the rest $\left(p\right.$-value $\left.<2.2 \times 10^{-16}\right)$. The post hoc analysis suggested that the means from the 1.9 and .5 inches are the statistically equal (Table 5). Likewise, the comparisons 1.0-1.27 inches, 1.27-1.4 inches, 1.27-2 inches, and the 1.4-1.9 had mean standard lengths statistically equal (Table 5). The remaining comparisons presented different means (Table 5).
Table 3. Mean standard length and percentage of organisms below the minimum size for the sardine caught in the Gulf of California during 2017-2018.

\begin{tabular}{ccc}
\hline Zone & Standard length & $\%$ \\
\hline I-G & $155.4 \pm 23.2$ & $37.6 \%$ \\
II-G & $159.5 \pm 12.9$ & $27.8 \%$ \\
III-G & $163.2 \pm 22.9$ & $19.8 \%$ \\
IV-G & $143.2 \pm 19.0$ & $72.1 \%$ \\
V-G & $158.9 \pm 16.0$ & $34.1 \%$ \\
VI-G & $155.2 \pm 21.8$ & $45.3 \%$ \\
VII-G & $163.3 \pm 17.0$ & $26.2 \%$ \\
VIII-G & $165.8 \pm 20.4$ & $23.4 \%$ \\
IX-G & $165.3 \pm 14.4$ & $11.4 \%$ \\
\hline
\end{tabular}



Figure 3. Cumulative distribution of the sardine's standard length caught by the small pelagic fishery in the Gulf of California. 
Table 4. Average standard ha length $(\mathrm{mm})$ by mesh size (inches) for the California sardine in the small pelagic fishery.

\begin{tabular}{lllllllll}
\hline Mesh size & 0.5 & 1 & 1.2 & 1.27 & 1.3 & 1.4 & 1.9 & 2 \\
\hline Average standard length & 150.2 & 159.6 & 169.4 & 156.7 & 163.5 & 154.5 & 150.2 & 156.6 \\
Sample size & 385 & 3236 & 467 & 204 & 1575 & 1088 & 206 & 1153 \\
\hline
\end{tabular}

We also estimated the percentage of California sardine below the minimum size by Zone-Month combination (Table 6). The Observer program did not cover all Zone-Month combinations. In general, the highest percentages corresponded to June and July, although some high values showed up for May and December (Table 6). The overall highest percentages corresponded to May-June in the Zone IX-G and December in zone IX-G. However, the Zone IV-G presented consistently higher percentages throughout the year (Fig. 1, Table 6) and the highest percentage by Zone (Table 3). Zone VI-G also presented high percentages during some months of the year (Table 6).

Table 5. Results for the posthoc Kruskal-Wallis test for the California sardine standard length regarding mesh size.

\begin{tabular}{|c|c|c|}
\hline Comparison & Value & $\operatorname{Pr}(>||)$ \\
\hline $1-0.5=0$ & 14.001 & $7.1942 \times 10^{-14}$ \\
\hline $1.2-0.5=0$ & 21.813 & $<2.22 \times 10^{-16}$ \\
\hline $1.27-0.5=0$ & 6.277 & 0.00024276 \\
\hline $1.3-0.5=0$ & 16.931 & $<2.22 \times 10^{-16}$ \\
\hline $1.4-0.5=0$ & 5.630 & 0.00176400 \\
\hline $1.9-0.5=0$ & 0.003 & 1.0 \\
\hline $2-0.5=0$ & 8.771 & $1.5606 \times 10^{-08}$ \\
\hline $1.2-1=0$ & 15.084 & $7.2053 \times 10^{-14}$ \\
\hline $1.27-1=0$ & 2.917 & 0.43945205 \\
\hline $1.3-1=0$ & 6.762 & $4.7617 \times 10^{-05}$ \\
\hline $1.4-1=0$ & 12.027 & $7.6161 \times 10^{-14}$ \\
\hline $1.9-1=0$ & 8.600 & $3.3417 \times 10^{-08}$ \\
\hline $2-1=0$ & 6.963 & $2.3371 \times 10^{-05}$ \\
\hline $1.27-1.2=0$ & 11.394 & $1.2401 \times 10^{-13}$ \\
\hline $1.3-1.2=0$ & 10.219 & $1.3972 \times 10^{-11}$ \\
\hline $1.4-1.2=0$ & 21.121 & $<2.22 \times 10^{-16}$ \\
\hline $1.9-1.2=0$ & 15.374 & $7.6161 \times 10^{-14}$ \\
\hline $2-1.2=0$ & 17.970 & $<2.22 \times 10^{-16}$ \\
\hline $1.3-1.27=0$ & 5.620 & 0.00181195 \\
\hline $1.4-1.27=0$ & 2.754 & 0.51786870 \\
\hline $1.9-1.27=0$ & 4.902 & 0.01236371 \\
\hline $2-1.27=0$ & 0.367 & 0.99999614 \\
\hline $1.4-1.3=0$ & 15.963 & $1.2434 \times 10^{-14}$ \\
\hline $1.9-1.3=0$ & 10.743 & $9.0106 \times 10^{-13}$ \\
\hline $2-1.3=0$ & 11.524 & $1.0658 \times 10^{-13}$ \\
\hline $1.9-1.4=0$ & 3.658 & 0.16059034 \\
\hline $2-1.4=0$ & 4.321 & 0.04652954 \\
\hline $2-1.9=0$ & 5.677 & 0.00153530 \\
\hline
\end{tabular}

Additionally, we calculated the mean standard length by boat (Table 7). Six boats had an average standard length below the minimum size established. Those boats presented percentages greater than the tolerance limit established by the regulation (20\%); for example, the boat 27 caught $100.0 \%$ of organisms below the $150 \mathrm{~mm}$ (Table 7). They did 24 sets in the zone VI during the month of July. Likewise, the Boat 6 caught $98.5 \%$ of sardines below the size limit, while operating in the zone IV during June and used a 0.5 inches mesh size. We found out that boats catching more of $40 \%$ of organisms below the established minimum size mostly operated in the fishing zones IV-G and VI during June and July (Table 7); in zones IV-G and VI-G, the sardines caught had an average standard length of $143.2 \pm 19.0 \mathrm{~mm}$ and $155.2 \pm$ 21.8 respectively. Their percentages below the size limit are $72.1 \%$ and $45.3 \%$ (Table 3). Data from the observer Program suggest these zones are characterized by small organisms in the maturity stages 2,3 , and 4 (gonads in development, in the maturity process, and pre-spawning).

Concerning correlations between covariates, none of the correlations between the standard length and the other covariates were high (Table 8); the biggest correlation for the standard length corresponded to month $\left(\rho=0.22, p\right.$-value $\left.=2.2 \times 10^{-16}\right)$. The overall highest correlation corresponded to latitude-longitude $\left(\rho=0.90, p\right.$-value $\left.=2.2 \times 10^{-16}\right)$. Other higher correlations were seine length-seine height, month-latitude, and month-longitude; the remaining correlations were low (Table 8).

Results from the ANCOVA model (Eq. 1) fitted to the Gulf of California data are shown below (Table 9). Out of the 78 original variables and interactions, the model selection process dropped 18 predictors from the model. The minimal model included 60 significant predictors. Six covariates were significant: mesh size, latitude, longitude, depth, seine length and seine height. All six factors were significant (Table 9). The model explained $82.2 \%$ of the observed variability in the standard length. According to the ANOVA results, the predictor variable explaining most of the observed variability was the factor Month (31.5\%). The second most important predictor was the factor year $(9.5 \%)$. The factors boat (7.2\%) and maturity (5.1\%) explained also important amount of the variability. Fishing gear covariates (mesh size, seine length and seine height) explained a small amount of variability observed; in particular, Mesh size explained 1.5\%. The remaining covariates explained less than 1\% (Table 7). In general, first-level interactions explained less than $4 \%$ of the observed variability; the interaction explaining most variability was Month:Boat (3.4\%). The Month:Year interaction explained $3.1 \%$ and Month:Longitude explained $2.1 \%$. As shown, most of the interactions explaining an important amount of variability were related to the factor Month. The factors month, boat and their interaction explained $42.2 \%$ of the variability observed. Likewise, the factor Month and its interactions explained $24.6 \%$ of the observed variability. 




Figure 4. Monthly variation of sardine's standard length caught by the small pelagic fishery in the Gulf of California.

Table 6. Percentage of Monterrey sardines below the minimum size by Zone and Month in the Gulf of California; FC - fishing closure, Avg - average of percentage of sardine below the minimum size.

\begin{tabular}{lcccccccccc}
\hline & I-G & II-G & III-G & IV-G & V-G & VI-G & VII-G & VIII-G & IX-G & Avg \\
\hline Jan & - & - & - & - & 43.4 & - & 29.5 & 0.0 & & 24.3 \\
Feb & - & - & - & - & - & - & 0.0 & 36.0 & & 18.0 \\
Mar & 8.1 & 27.9 & 0.0 & 50.0 & 0.0 & 0.0 & - & - & 0.3 & 12.3 \\
Apr & - & - & 0.6 & 0.0 & 0.0 & - & - & - & 0.0 & 0.2 \\
May & 98.4 & - & 10.2 & 50.0 & - & 0.0 & - & 0.0 & 100.0 & 43.1 \\
Jun & - & - & 74.0 & - & - & 79.5 & - & 71.4 & 100.0 & 81.2 \\
Jul & - & - & - & 91.8 & - & 91.7 & - & 0.0 & & 61.2 \\
Aug & FC & FC & FC & FC & FC & FC & FC & FC & FC & FC \\
Sep & FC & FC & FC & FC & FC & FC & FC & FC & FC & FC \\
Oct & - & - & - & - & 42.6 & - & - & - & & 42.6 \\
Nov & 6.2 & - & 18.5 & 65.8 & 50.0 & 45.5 & - & 13.7 & 14.7 & 30.6 \\
Dec & 0.0 & - & - & - & - & 100.0 & - & - & 10.5 & 36.8 \\
\hline
\end{tabular}


Table 7. California sardine mean standard length by boat for the Gulf of California; * - mean standard length below the minimum size established by regulations, \% percentage of organisms with standard length below the minimum size.

\begin{tabular}{|c|c|c|c|c|c|}
\hline Boat & Mean (mm) & $\%$ & Zone and sample size & Months and sample size & $\begin{array}{c}\text { Mesh } \\
\text { size }\end{array}$ \\
\hline Boat 1 & $153.0 \pm 19.5$ & $46.0 \%$ & I (77), III (19), IV (44), V(32), VI (19), VI (28), IX (209) & $\begin{array}{l}\text { Jan (53), May (77), June (77), Jul (19), Nov (133), } \\
\text { Dec (69) }\end{array}$ & 1.0 \\
\hline Boat 2 & $150.2 \pm 16.2$ & $58.5 \%$ & III (42), IV (81), V (64), IX (19) & Feb (71), Mar (67), Jun (35), Jul (20), Dec (13) & 1.9 \\
\hline Boat 3 & $131.2 \pm 12.3$ & $94.8 \%$ & III (27), IV (96), VI (71) & Jun (81), Jul (113) & 1.4 \\
\hline Boat 4 & $157.4 \pm 16.4$ & $43.4 \%$ & IV (21), V (289), VII (37), IX (19) & Oct (38), Nov (328) & 1.4 \\
\hline Boat 5 & $164.6 \pm 13.8$ & $17.3 \%$ & II (59), III (120), IV (28), V (68), VI (41), VII (95) & Mar (59), Apr (70), May (91), Oct (28), Nov (163) & 2.0 \\
\hline Boat 6 & $130.5 \pm 11.2$ & $98.5 \%$ & IV-G (65) & Jun (65) & 0.5 \\
\hline Boat 7 & $147.8 \pm 24.0$ & $45.2 \%$ & I (46), III (23), IV (20), VI (15), IX (156) & $\begin{array}{l}\text { Jan (56), Feb (30), Apr (22), May (56), Jun (43), Jul } \\
\text { (15), Dec (35) }\end{array}$ & 1.27 \\
\hline Boat 8 & $169.4 \pm 20.5$ & $12.0 \%$ & I-G (119), III-G (30), IV-G (20), V-G (49), IX-G (249) & $\begin{array}{l}\text { Jan (19), Feb(79), Mar (188), May (30), Jun (20), } \\
\text { Nov (131) }\end{array}$ & 1.2 \\
\hline Boat 9 & $166.7 \pm 21.9$ & $22.6 \%$ & III (80), V (216), VI (25), VII (42), VIII (64) & Feb (21), Apr (56), Jun (49), Oct (55), Nov (246) & 1.3 \\
\hline Boat 10 & $159.5 \pm 21.1$ & $37.8 \%$ & II (20), III (47), IV (61), V (162), VI 46), VII (44), IX (20) & Jan (20), Mar (42), May (84) Jul (70), Nov (11) & 1.3 \\
\hline Boat 11 & $159.1 \pm 9.6$ & $19.4 \%$ & III-G (29), V-G (21), IX-G (22) & Jan (21), Feb (51) & 1.4 \\
\hline Boat 12 & $162.9 \pm 16.3$ & 20.9 & I (96), IV (96), V (61), VIII (20), IX (145) & Feb (167), Mar (74), Jun (71), Jul (45), Nov (61) & 1.0 \\
\hline Boat 13 & $162.4 \pm 6.8$ & $3.7 \%$ & I (64), IV (14), V (60), VIII (25), IX (298) & $\begin{array}{l}\text { Jan (160), Mar (114), Jun (14), Oct (45), Nov (49), } \\
\text { Dec (79) }\end{array}$ & 1.0 \\
\hline Boat 14 & $164.6 \pm 14.6$ & $23.2 \%$ & III (118), IV (22), V (48), VI (58), VIII (30) & Apr (87), May (112), Nov (65), Dec (12) & 1.4 \\
\hline Boat 15 & $167.5 \pm 14.1$ & $12.7 \%$ & III (20), V (103), VI (21), IX (147) & $\begin{array}{l}\text { Jan (35), Feb (15), Mar (30), Apr (37), May (21), Nov } \\
\text { (153) }\end{array}$ & 1.0 \\
\hline Boat 16 & $144.9 \pm 17.9$ & $57.9 \%$ & I (26), III (15), IV (45), VI (22), IX (128) & Jan (34), May (66), Jun (56), Jul (15), Nov (43), Dec (22) & 1.0 \\
\hline Boat 17 & $165.1 \pm 20.9$ & $27.5 \%$ & $\begin{array}{l}\text { III (110), IV (201), V (129), VI (46), VII (36), VIII (89), IX } \\
(20)\end{array}$ & $\begin{array}{l}\text { Mar (3), Apr (53), May (110), Jun (122), Jul (92), Oct } \\
\text { (42), Nov (192) }\end{array}$ & t 1.3 \\
\hline Boat 18 & $156.5 \pm 21.9$ & $32.5 \%$ & $\begin{array}{l}\text { III-G (127), IV-G (56), V-G (115), VI-G (78), VII-G (23), } \\
\text { VIII-G (19) }\end{array}$ & $\begin{array}{l}\text { Jan (19), Feb (23), Mar (31), Apr (36), May (87), Jun } \\
\text { (33), Jul (47), Oct (24), Nov (118) }\end{array}$ & 1.0 \\
\hline Boat 19 & $161.2 \pm 20.8$ & $35.6 \%$ & III (109), IV (80), V (162), VI (26), VII (1), VIII (27), IX (35) & $\begin{array}{l}\text { Jan (25), Feb (61), Mar (16), Apr (38), May (41), Jun } \\
\text { (136), Jul (26), Oct (1), Nov (69), Dec (27) }\end{array}$ & 1.0 \\
\hline Boat 20 & $156.5 \pm 14.2$ & $37.1 \%$ & IV (34), V (22), VII (61) & Jan (61), Nov (56) & 1.3 \\
\hline Boat 21 & $136.5 \pm 23.4$ & $65.9 \%$ & III-G (21), IV-G (91), V-G (26), & Jan (26), Jun (21), Jul (91) & 2 \\
\hline Boat 22 & $154.2 \pm 18.0$ & $49.8 \%$ & III (55), V (265) & Feb (80), May (24), Oct (51), Nov (165) & 0.5 \\
\hline Boat 23 & $156.7 \pm 11.1$ & $29.4 \%$ & III (63), V (92), VIII (25) & Jan (76), Feb (25), Apr (31), May (48) & 1.4 \\
\hline Boat 24 & $155.7 \pm 15.8$ & $23.6 \%$ & III (44), IV (34), V (86), VII (31) & Feb (44), Jun (78), Nov (53), Dec (20) & 2.0 \\
\hline Boat 25 & $151.6 \pm 19.2$ & $34.4 \%$ & III-G (54), IV-G (25), V-G (110) & Feb (26), Jun (79), Nov (84) & - \\
\hline Boat 26 & $155.8 \pm 12.4$ & $36.4 \%$ & III-G (91), IV-G (37), V-G (199), VI-G (22), VII-G (60) & Jan (18), Apr (46), May (113), Oct (41), Nov (191) & 2 \\
\hline Boat 27 & $125.3 \pm 17.2$ & $100 \%$ & VI-G (24) & Jul (24) & - \\
\hline Boat 28 & $162.7 \pm 17.6$ & $32.9 \%$ & I-G (187), IV (48), IX-G (263) & Feb (170), Mar (161), May (99), Jun (43), Jul (25) & 1.0 \\
\hline Boat 29 & $168.9 \pm 22.0$ & $28.9 \%$ & VII (46) & Nov (11) & 1.0 \\
\hline
\end{tabular}

\section{DISCUSSION}

Yield overfishing prevents a population from producing as much sustainable yield as it could if less intensively fished. Growth overfishing is a component of yield overfishing, and it happens when a fishery catches fish still growing (Hilborn \& Hilborn, 2012). The ideal time to catch fish is when they stop growing; otherwise, the fishery is wasting the poten- tial growth of each small fish caught too young. How much a fishery overfishes the yield depends on a mixture of recruitment overfishing and growth overfishing (Hilborn \& Hilborn, 2012). In Mexico, the official technical regulation NOM-003-SAG/PESC-2018 (SADER, 2019) includes measures to avoid growth overfishing, such as the minimum size (150 mm for California Sardine) and the $20 \%$ limit for fish below the minimum size in the total annual catch. Results from our analysis sug- 
gest that $32.9 \%$ of the fish caught in the Gulf of California are below the minimum size, $12.9 \%$ above the tolerance limit. Failure to comply with this regulation could be considered as implementation error. According to Charles (2001), the very existence of this form of uncertainty is due in large part to the limited nature of communication between fishermen and managers, and in particular, uncertainties which management faces in understanding and predicting: a) the objectives being pursued by fishers; b) the factors driving fishermen decision making; c) the response of fishermen to specific regulations and d) the effectiveness of enforcement measures.

In the particular case of the Mexican small pelagic fishery, fishermen could ask: what can we do to fully meet the regulations to avoid growth overfishing? There is not an easy answer to this question. Currently, the mesh size allowed in the small pelagic fishery ranges from 13 to $25 \mathrm{~mm}$ (SADER, 2019). Data from the Observer Program suggest that the fishery complies with this regulation. A simple and controversial answer could be the use of a greater mesh size. Although this answer could make sense, some precisions are needed. One objective of mesh size regulations is to influence the sustainable yield in the longterm. Another objective is the protection of juvenile fish from capture and trying to ensure that sufficient fish survive to maturity (FA0, 1984). There are several difficulties with mesh regulations, one of which is that it is not usually possible to demonstrate that an actual change in mesh size has had the expected effect on catches. This is because stock size (and catch) natural fluctuations tend to be much larger than the expected effects of the implemented mesh size changes. Managers should also consider that the effects of regulations, like this one, are hardly measurable without an observer program and adequate monitoring at dock ports. This does not necessarily mean that mesh regulations do not affect. It does mean that the effects of mesh regulations are difficult to demonstrate in practice. Our results, based on the Observer Program's data, did not find a clear relationship between the average standard length and the mesh size, suggesting other predictor variables are responsible for the length variation. Due to these facts, and because the short-term effect of a mesh increase is likely a catch reduction, it may be difficult convincing the industry that such restrictive measures are really necessary (FAO, 1984).

We mainly based our approach on ANCOVA models (Eq. 1). We included several predictor variables; our results suggest that the standard length variability does not depend on one but several predictor variables. In particular, results from the ANCOVA and the ANOVA models suggested that although mesh size was significant, it did not explain an important amount of the standard length variability (1.3\%). Therefore, results suggest that the mesh size might not be the main predictor variable responsible for the variability observed in the California sardine standard length and the capture of small fish; thus, its use in the fishery was adequate for the period analyzed. Results also suggested that the remaining significant covariates explained small amounts of observed variability. Contrarily, factors (Month, Year, Sex, Maturity, Zone, and Boat) explained larger amounts of the observed variability; in general, interactions explained smaller amounts of observed variability. In particular, the factor Year explained an important amount of observed variability, and the means for 2017 and 2018 were significantly different. This could be the effect of incomplete data. In 2017 the Observer Program started sampling in May, so they did not collect data from January to April, months characterized by the presence of larger organisms. This could be the cause of the difference between the means and the importance of the year factor in explaining the fish size variability.

The factors Month, Boat and their interaction explained $42.2 \%$ of the variability observed. The main driver for the sardine length was Month. Results suggested that for June and July, the mean standard length was smaller than the minimum size. Consequently, during those months the percentage of sardine below the size limit was greater than $60 \%$. This effect was more intense in zones IV and VI, where just a few ships operated during those months.

Regarding the factor Boat, six boats had a mean standard length smaller than the minimum size. They also have larger percentages of fish below the size limit. Our analysis also suggests that these six ships caught a large number of small sardines while operating mostly in Zone IV-G and VI-G during June and July. Data from the observer Program suggest that immature juveniles characterize these zones during June and July. In this regard, sardine catches are related to permanent and highly dynamic migratory processes (Sokolov, 1973; Hammann et al.,1988; Cisneros-Mata et al., 1988) and environmental variability (De Anda-Montañez et al., 1994, Lluch-Belda et al., 1996, Nevárez-Martínez et al., 2008). Because the reproductive processes are related to this variability, the presence of small organisms in zones IV and VI is likely to depend on these processes. Sokolov \& Wong-Rios (1973) and Sokolov (1974) postulated that sardine juveniles are found mainly on the Gulf west coast due to transportation from the east coast. Two aspects: reproduction in nearby upwelling areas and the supply of eggs and larvae from other areas, would explain the greater presence of juveniles in such zones. Thus, age-dependent availability to the fishery likely depends upon the location of the fishery operations.

Table 8. Covariate correlations. L-standard length, SL-seine length, MS-mesh size, Lat-latitude, Lon-longitude, SH-seine height.

\begin{tabular}{|c|c|c|c|c|c|c|c|c|}
\hline & $\mathrm{L}$ & Month & $\mathrm{SL}$ & MS & Depth & Lat & Lon & SH \\
\hline $\mathrm{L}$ & 1.00 & 0.22 & -0.12 & -0.06 & -0.05 & -0.14 & -0.22 & 0.09 \\
\hline Month & & 1.00 & -0.22 & 0.10 & 0.10 & 0.39 & 0.37 & 0.09 \\
\hline SL & & & 1.00 & 0.09 & -0.09 & -0.04 & -0.02 & 0.40 \\
\hline MS & & & & 1.00 & 0.16 & -0.09 & -0.08 & 0.23 \\
\hline Depth & & & & & 1.00 & 0.06 & 0.09 & -0.12 \\
\hline Lat & & & & & & 1.00 & 0.90 & 0.10 \\
\hline Lon & & & & & & & 1.00 & 0.07 \\
\hline $\mathrm{SH}$ & & & & & & & & 1.00 \\
\hline
\end{tabular}


Table 9. ANOVA for the minimal model determined for the standard length as response variable; Df-degrees of freedom, Sum Sq-Sum of squares, Mean Sq-Mean squares, \% percentage of standard length variability explained by the predictor variable, SL-seine length, SH-seine height, MSmesh size

\begin{tabular}{|c|c|c|c|c|c|c|}
\hline & $\mathrm{Df}$ & Sum Sq & Mean Sq & Fvalue & $\operatorname{Pr}(>F)$ & $\%$ \\
\hline Month & 9 & 787457.828 & 87495.3143 & 1230.78819 & 0 & 31.45 \\
\hline Year & 1 & 238122.916 & 238122.916 & 3349.65222 & 0 & 9.51 \\
\hline Mesh size & 1 & 38510.3609 & 38510.3609 & 541.721553 & $5.43 \times 10^{-115}$ & 1.54 \\
\hline Depth & 1 & 695.380075 & 695.380075 & 9.78184482 & 0.00177052 & 0.03 \\
\hline SL & 1 & 477.85041 & 477.85041 & 6.72187588 & 0.0095459 & 0.02 \\
\hline SH & 1 & 620.181939 & 620.181939 & 8.72403985 & 0.0031521 & 0.02 \\
\hline Latitude & 1 & 3473.47994 & 3473.47994 & 48.8611091 & $3.03 \times 10^{-12}$ & 0.14 \\
\hline Longitude & 1 & 868.133387 & 868.133387 & 12.2119491 & 0.00047813 & 0.03 \\
\hline Sex & 4 & 48812.7183 & 12203.1796 & 171.660957 & $1.04 \times 10^{-139}$ & 1.95 \\
\hline Maturity & 6 & 127819.986 & 21303.331 & 299.671914 & 0 & 5.10 \\
\hline Zone & 8 & 15925.9951 & 1990.74939 & 28.0036807 & $3.46 \times 10^{-43}$ & 0.64 \\
\hline Boat & 23 & 180493.701 & 7847.55223 & 110.390764 & 0 & 7.21 \\
\hline Month:Year & 4 & 77868.4138 & 19467.1035 & 273.841877 & $3.04 \times 10^{-217}$ & 3.11 \\
\hline Month:MS & 9 & 12625.9074 & 1402.8786 & 19.7341587 & $5.01 \times 10^{-33}$ & 0.50 \\
\hline Month:Depth & 9 & 23466.4003 & 2607.37781 & 36.6777336 & $5.95 \times 10^{-64}$ & 0.94 \\
\hline Month:SL & 9 & 29171.8373 & 3241.31525 & 45.5952707 & $4.28 \times 10^{-80}$ & 1.17 \\
\hline Month:SH & 9 & 15801.0308 & 1755.67009 & 24.6968428 & $4.2510^{-42}$ & 0.63 \\
\hline Month:Latitude & 9 & 12691.4965 & 1410.16627 & 19.8366737 & $3.2610^{-33}$ & 0.51 \\
\hline Month:Longitude & 9 & 51564.1653 & 5729.3517 & 80.5942409 & $5.0610^{-142}$ & 2.06 \\
\hline Month:Sex & 17 & 7362.83499 & 433.10794 & 6.09248786 & $2.6310^{-14}$ & 0.29 \\
\hline Month:Maturity & 37 & 25849.5802 & 698.637303 & 9.82766393 & $1.7910^{-53}$ & 1.03 \\
\hline Month:Zone & 25 & 24137.63 & 965.505198 & 13.581669 & $3.0510^{-55}$ & 0.96 \\
\hline Month:Boat & 50 & 86199.1787 & 1723.98357 & 24.2511116 & $3.4110^{-200}$ & 3.44 \\
\hline Year:MS & 1 & 5874.82185 & 5874.82185 & 82.6405554 & $1.3010^{-19}$ & 0.23 \\
\hline Year:SH & 1 & 937.75404 & 937.75404 & 13.1912961 & 0.0002835 & 0.04 \\
\hline Year:Longitude & 1 & 4203.77199 & 4203.77199 & 59.1340574 & $1.70 \times 10^{-14}$ & 0.17 \\
\hline Year:Sex & 2 & 1223.45571 & 611.727857 & 8.60511709 & 0.00018534 & 0.05 \\
\hline Year:Maturity & 5 & 2639.03598 & 527.807195 & 7.42461319 & $5.93 \times 10^{-07}$ & 0.11 \\
\hline Year:Zone & 2 & 729.696868 & 364.848434 & 5.13228792 & 0.00592791 & 0.03 \\
\hline Year:Boat & 3 & 3299.05005 & 1099.68335 & 15.4691402 & $5.04 \times 10^{-10}$ & 0.13 \\
\hline MS:Depth & 1 & 14524.5862 & 14524.5862 & 204.31596 & $1.24 \times 10^{-45}$ & 0.58 \\
\hline MS:SL & 1 & 7005.12354 & 7005.12354 & 98.5404009 & $4.71 \times 10^{-23}$ & 0.28 \\
\hline MS:SH & 1 & 715.132912 & 715.132912 & 10.0597061 & 0.0015228 & 0.03 \\
\hline MS:Sex & 2 & 1149.62007 & 574.810033 & 8.08579761 & 0.00031111 & 0.05 \\
\hline MS:Maturity & 5 & 1264.72725 & 252.94545 & 3.55815938 & 0.00324917 & 0.05 \\
\hline Mesh size:Zone & 6 & 5938.39206 & 989.73201 & 13.9224653 & $8.53 \times 10^{-16}$ & 0.24 \\
\hline Depth:SL & 1 & 9936.35575 & 9936.35575 & 139.773763 & $6.51 \times 10^{-32}$ & 0.40 \\
\hline Depth:SH & 1 & 1634.73764 & 1634.73764 & 22.9956976 & $1.66 \times 10^{-06}$ & 0.07 \\
\hline
\end{tabular}


Table 9. (Continúa)

\begin{tabular}{lcrllll}
\hline & Df & Sum Sq & \multicolumn{1}{c}{ Mean Sq } & \multicolumn{1}{c}{ Fvalue } & \multicolumn{1}{c}{$\operatorname{Pr}(>\mathrm{F})$} & $\%$ \\
\hline Depth:Latitude & 1 & 7312.64175 & 7312.64175 & 102.86623 & $5.49 \times 10^{-24}$ & 0.29 \\
Depth:Sex & 3 & 1186.82097 & 395.60699 & 5.56496558 & 0.00082466 & 0.05 \\
Depth:Maturity & 5 & 1683.62248 & 336.724497 & 4.7366712 & 0.00025408 & 0.07 \\
Depth:Zone & 8 & 15511.0325 & 1938.87907 & 27.2740259 & $5.38 \times 10^{-42}$ & 0.62 \\
Depth:Boat & 21 & 37060.5143 & 1764.78639 & 24.8250809 & $7.18 \times 10^{-93}$ & 1.48 \\
SL:Latitude & 1 & 960.529054 & 960.529054 & 13.5116701 & 0.00023907 & 0.04 \\
SL:Longitude & 1 & 1517.35543 & 1517.35543 & 21.3444933 & $3.91 \times 10^{-06}$ & 0.06 \\
SL:Sex & 2 & 575.820113 & 287.910057 & 4.05000315 & 0.01746801 & 0.02 \\
SL:Maturity & 5 & 3184.18078 & 636.836155 & 8.95831311 & $1.71 \times 10^{-08}$ & 0.13 \\
SH:Latitude & 1 & 990.503763 & 990.503763 & 13.9333214 & 0.00019109 & 0.04 \\
SH:Longitude & 1 & 3683.26169 & 3683.26169 & 51.8120889 & $6.82 \times 10^{-13}$ & 0.15 \\
SH:Maturity & 5 & 3968.5722 & 793.71444 & 11.1651049 & $9.86 \times 10^{-11}$ & 0.16 \\
SH:Zone & 6 & 12344.4839 & 2057.41399 & 28.9414453 & $2.34 \times 10^{-34}$ & 0.49 \\
Latitude:Zone & 6 & 12209.1067 & 2034.85112 & 28.6240555 & $5.79 \times 10^{-34}$ & 0.49 \\
Latitude:Boat & 20 & 33208.0071 & 1660.40036 & 23.3566925 & $4.67 \times 10^{-83}$ & 1.33 \\
Longitude:Zone & 6 & 6578.67495 & 1096.44583 & 15.4235983 & $1.22 \times 10^{-17}$ & 0.26 \\
Longitude:Boat & 18 & 17129.6628 & 951.647934 & 13.3867402 & $4.01 \times 10^{-40}$ & 0.68 \\
Sex:Maturity & 12 & 1649.0179 & 137.418159 & 1.93304806 & 0.02629927 & 0.07 \\
Sex:Zone & 13 & 3349.70113 & 257.669318 & 3.62460958 & $9.72 \times 10^{-06}$ & 0.13 \\
Sex:Boat & 34 & 6159.63641 & 181.165777 & 2.54844161 & $1.98 \times 10^{-06}$ & 0.25 \\
Maturity:Zone & 29 & 3671.9928 & 126.620441 & 1.7811576 & 0.00611249 & 0.15 \\
Maturity:Boat & 65 & 14120.2244 & 217.234222 & 3.05581297 & $3.85 \times 10^{-15}$ & 0.56 \\
Residuals & 6257 & 444802.919 & 71.0888476 & NA & $N A$ & 17.76 \\
\hline
\end{tabular}

Our results suggest that compliance with the official technical regulation requires that fishery boats avoid or reduce their operations during June and July. This measure would help to avoid growth overfishing, contributing to better management. However, this measure could face the fishermen's opposition because they already face a closed season (September and October). A better approach, it would be a partial closure during June and July, restricting fishing operations on Zones IV-G and VI-G. This measure would face less opposition since only a few boats carried out an important number of sets in those zones during those months. Full compliance with this regulation would require that the Comisión Nacional de Acuacultura y Pesca CONAPESCA (National Aquaculture and Fisheries Commission) and fishermen reach a consensus on this regard. This measure would be less restrictive and could be adopted and enforced with less opposition by fishermen.

Enforcing this proposal is relatively easy. Currently, the fishery is making important efforts to achieve sustainability, including keeping the MSC certification, the Observer Program, regulation development, and the setting of a Vessel Monitoring System VMS. The information collected by VMS is of great importance in the knowledge of the fishing fleet's behavior because it locates precisely any boat and provides the opportu- nity of collecting and processing information that could contribute to the comprehension of the fishing effort application and the fishing season development. With the VMS, CONAPESCA could enforce the reduction of fishing operations during the proposed months and zones relatively easily with no extra cost because the VMS is fully implemented and operating.

The onboard observer program is a useful tool able to provide information for scientific research and management; it also provides information useful to maintain the MSC certification and contributes to the overall sustainability. This program must continue (under an independent scheme from ship owners and government research centers) gathering data that could improve the understanding of the fishery dynamics and characterize with precision the temporal trend of the standard length to help to set up and improve management measures. Results from our work, based on the observer program data, contribute to provide additional information to avoid growth overfishing and consequently yield overfishing. They also support the important efforts (MSC certification, observer program, development and updating of fishing regulations, VMS, etc.) that managers and fishermen are making to assure the sustainable exploitation of this fishing resource, the reduction of the fishing impacts, and the economic benefits. 


\section{REFERENCES}

Charles, A. 2001. Sustainable Fishery Systems. Blackwell Science Ltd. 0xford, UK. $370 \mathrm{p}$.

Cisneros-Mata, M. A., J. A. de Anda, J. J. Estrada, F. Paéz y A. Quiroz. 1988. Pesquerías de sardina del Golfo de California y costa de Sinaloa (informe 1986/87 y diagnostico). Secretaría de Pesca, Instituto Nacional de Pesca, Guaymas. $66 \mathrm{p}$.

Cisneros-Mata M. A., M. O. Nevárez-Martínez \& M. G. Hammann. 1995. The rise and fall of the Pacific sardine, Sardinops sagax caeruleus Girard, in the Gulf of California, Mexico. California Cooperative Oceanic Fisheries Investigations Reports 36: 136-143.

Crawley, M. J. 2007. The R Book. John Wiley and Sons, Ltd. West Sussex, England. 942 p.

De Anda-Montañez, J. A., J. C. Seljo, S. Martínez. 1994. Reclutamiento y variabilidad ambiental en la pesquería de sardina monterrey (Sardinops sagax) del Golfo de California, México. Investigación Pesquera 38: 23-36.

FAO (Food and Agriculture Organization). 1984. Papers presented at the Expert Consultation on the regulation of fishing effort (fishing mortality). Fisheries Report, 289(3):214. Available online at: http:// www.fao.org/3/AC750E/AC750E00.htm (downloaded March 26, 2020).

Gómez-Muñoz V. M., C. Quiñonez-Velázouez \& R. Félix-Uraga. 1991. Distribución de las especies de carnada de la flota varera mexicana, durante 1988 a 1990. Resúmenes del II Congreso Nacional de Ictiología. SIMAC. San Nicolás de los Garza, Nuevo León.

Hammann, M. G., T. R. Baumgartner \& A. Badan-Dangon. 1988. Coupling of the Pacific Sardine (Sardinops sagax caeruleus) life cycle with the Gulf of California pelagic environment. California Cooperative Oceanic Fisheries Investigations Report 29: 102-109.

Hernández, C. H. \& Jurado J. 2018. Informe técnico del Programa de observadores técnicos a bordo de la flota mayor de sardina, en el Océano Pacífico y arrastreros de la costa Occidental de Baja California. Temporada de pesca 2017-2018. CONAPESCA, Mazatlán, Sinaloa. $161 p$.

HILBORN R. \& U. HILBORN. 2012. Overfishing what everyone needs to know. Oxford University Press, Inc. Oxford, New York. 131p.

INAPESCA (Instituto Nacional de Pesca). 2012. Acuerdo por el que se da a conocer el Plan de Manejo Pesquero para la pesquería de Pelágicos menores (sardinas, anchovetas, macarelas y afines) del Noroeste de México. Diario Oficial de la Federación. México, D.F. Octubre 10: 51. Disponible en línea en: https://www.inapesca.gob.mx/portal/ documentos/Planes-de-Manejo-Pesquero/Pacifico/Plan-de-Manejo-Pesquero-para-la-Pesqueria-de-Pelagicos-Menores.pdf (consultado el 3 febrero 2020).

INAPESCA (Instituto Nacional de Pesca). 2018. Acuerdo por el que se da a conocer la actualización de la Carta Nacional Pesquera. Diario Oficial de la Federación. México, D.F. Junio 11:106. Disponible en línea en: http://dof.gob.mx/nota_detalle.php?codigo $=5525712 \&-$ fecha=11/06/2018 (consultado el 14 marzo 2020).
Jacob C. M., J. R. Vallarta, J. Payán, D. Becerra, J. R. Rendón, R. Villaseñor, C. H. Hernández \& J. Jurado-Molina. 2018. Manual de operaciones del Programa de observadores técnicos a bordo de la flota mayor de sardina, en el Océano Pacífico incluyendo el Golfo de California. Comisión Nacional de Acuacultura y Pesca, Instituto Nacional de Pesca y Global Grupo, Mazatlán, México. 77 p.

Lluch-Belda, D. \& F. J Magallón. 1986. Large fluctuations in the sardine fishery in the Gulf of California: Possible causes. California Cooperative Oceanic Fisheries Investigations Reports 27: 136-140.

Lluch-Belda, D., J. Arvizu, S. Hernández-Vázquez, D. B. Lluch-Cota, C. A. Sallnas-Zavala, T. Baumgartner, G. Hammann, A. Cota-Villavicencio, C. E. Cotero, W. Garcia-Franco, 0. Pedrín-Osuna, Y. Green-Ruíz, S. Lizárraga-Saucedo, M. Á. Martínez-Zavala, R. Morales-Azpeitia, M. 0. Nevárez-Martínez, J. P. Santos-Molina, R. I. Ochoa-Báez, R. Rodríguez- Sánchez, J. R. Torres-Villegas, F. PÁzz-BarRera. 1996. La pesquería de sardina y anchoveta. In: Sánchez-Palafox, A., D. F. Fuentes-Castellanos \& S. García-Real (eds.). Pesquerías Relevantes de México. Tomo I. Instituto Nacional de la Pesca. Secretaría de Pesca. México, pp. 419-535.

Mllzer, D. J. \& R. N. Lea. 1972. Guide to the coastal marine fishes of California. University of California Dept. of Fish and Game, Sacramento. 249 p.

Nevárez-Martínez, M. 0., M. Á. Cisneros-Mata, D. Lluch-Belda. 2008. Las capturas de sardina monterrey Sardinops sagax (Jenyns 1842) y su relación con el medio ambiente y el esfuerzo pesquero. In: López-Martínez, J. (ed.). Variabilidad ambiental y pesquerías de México. Comisión Nacional de Acuacultura y Pesca. México, pp. 183-200.

R. Core Team. 2018. R: A language and environment for statistical computing. R Foundation for Statistical Computing, Vienna, Austria. Available online at: https://www.R-project.org/ (downloaded January 15, 2020).

Rodríguez, R., S. Hernández, D. Lluch-Belda, R. Félix, S. Ortega, A. Villa, G. Ponce \& D. Lluch-CotA. 1996. Pesquería de pelágicos menores (sardina y anchovetas). In: Casas, M. \& G. Ponce (eds.). Estudio Potencial pesquero y acuícola de Baja California Sur. Vol. 1. Pesquerías Peces y Algas. SEMARNAP, pp. 317-350.

SAdER (Secretaría de Agricultura y Desarrollo Rural). 2019. Norma Oficial Mexicana NOM-003-SAG/PESC-2018, para regular el aprovechamiento de las especies de peces pelágicos menores con embarcaciones de cerco, en aguas de jurisdicción federal del Océano Pacífico, incluyendo el Golfo de California. Diario Oficial de la Federación. México, D.F. Diciembre 03: 15. Disponible en línea en: https://dof. gob.mx/nota_detalle.php?codigo $=5552552 \&$ fecha $=12 / 03 / 2019$ marzo (consultado el 7 marzo 2020).

Sokolov, V. A. \& M. Wong-Rios. 1973. Informe científico de las investigaciones sobre los peces pelágicos del Golfo de California (sardina, crinuda y anchoveta) en 1971. Contribuciones al estudio de las pesquerías de México. Secretaria de Pesca, Instituto Nacional de Pesca, México. 41p.

Sokolov, V. A. 1974. Investigaciones biológico-pesqueras de los peces pelágicos de California (sardina monterrey). Contribuciones al estudio de las pesquerías de México. Secretaria de Pesca, Instituto Nacional de Pesca, México. 11p. 